\title{
A new chromogenic agent for iron(III): Synthesis, structure and spectroscopic studies
}

\author{
CHANDRAMA BASU ${ }^{1}$, SANTANU CHOWDHURY ${ }^{1}$, HELEN STOECKLI-EVANS ${ }^{2}$ and \\ SOMA MUKHERJEE ${ }^{1 *}$ \\ ${ }^{1}$ Department of Environmental Science, University of Kalyani, Kalyani, Nadia 741235 \\ ${ }^{2}$ Institute of Physics, University of Neuchâtel, CH-2009 Neuchâtel, Switzerland \\ e-mail: sommukh445@yahoo.co.in
}

MS received 17 June 2009; revised 21 August 2009; accepted 26 August 2009

\begin{abstract}
A heterocyclic hydrazone ligand, diacetyl monoxime-2-pyridyl hydrazone, HL, 1, was investigated as a new chromogenic agent for selective detection of $\mathrm{Fe}^{3+}$. The ligand 1, undergoes $1: 2$ complexation with $\mathrm{Fe}^{3+}$ and $\mathrm{Ni}^{2+}$ to form complexes $\left[\mathrm{Fe}^{\mathrm{III}}(\mathrm{HL})_{2}\right] \mathrm{Cl}_{3}, \mathbf{1 a}$ and $\left[\mathrm{Ni}^{\mathrm{II}}(\mathrm{HL})_{2}\right] \mathrm{Cl}_{2}, \mathbf{1 b}$ respectively. The iron(III) complex 1a gives a characteristic absorption peak at $487 \mathrm{~nm}$ with distinct reddish-pink colouration. The change in colour can easily be distinguished from other metal complexes by the naked eye. No obvious interference was observed in presence of other metal ions $\left(\mathrm{Na}^{+}, \mathrm{K}^{+}, \mathrm{Ca}^{2+}, \mathrm{Mg}^{2+}, \mathrm{Al}^{3+}, \mathrm{Mn}^{2+}, \mathrm{Ni}^{2+}\right.$, $\left.\mathrm{Cu}^{2+}, \mathrm{Zn}^{2+}, \mathrm{Co}^{2+}, \mathrm{Pb}^{2+}, \mathrm{Hg}^{2+}, \mathrm{Cd}^{2+}\right)$. The bands appearing in the $\mathrm{UV}$ region $(200-340 \mathrm{~nm})$ are characteristics of the ligand, $\mathrm{HL}, \mathbf{1}$. In the complexes $\left[\mathrm{Fe}^{\mathrm{III}}(\mathrm{HL})_{2}\right] \mathrm{Cl}_{3}, \mathbf{1 a}$, and $\left[\mathrm{Ni}^{\mathrm{II}}(\mathrm{HL})_{2}\right] \mathrm{Cl}_{2}, \mathbf{1} \mathbf{b}$, these ligand centered bands are accompanied by multiple bands extending into the visible region $(350-500 \mathrm{~nm})$. The association constants $\left(K_{\text {ass }}\right.$, UV-Vis) were found to be $(6 \cdot 4865 \pm 0 \cdot 004) \times 10^{5}$ for the complex 1a and $(1.1960 \pm 0.002) \times 10^{5}$ for the complex $1 \mathbf{b}$ at $298 \mathrm{~K}$ determined by the UV-Vis spectroscopy. On excitation at $285 \mathrm{~nm}$, the ligand HL, 1 strongly emits at $364 \mathrm{~nm}$ due to an intraligand ${ }^{1}\left(\pi-\pi^{*}\right)$ transition. The complexes are luminescent $\left(\lambda_{\mathrm{ex}} 285 \mathrm{~nm}, \lambda_{\mathrm{em}} 365 \mathrm{~nm}\right)$ with $F / F_{0} 0.75$ for $\mathbf{1 a}$ and 0.81 for $\mathbf{1 b}$. In both the cases, the $1: 2$ binding is confirmed by Job's method. Molecular structure of the complex $\mathbf{1 b}$ has been determined by single crystal X-ray diffraction studies. Here, two crystallographically distinct but metrically very similar molecules making an enantiomeric pair constitute the asymmetric unit in which both metal atoms are tris chelated in meridional geometry.
\end{abstract}

Keywords. Chromogenic agent; luminescent compounds; spectroscopy; thermodynamic parameters; structure.

\section{Introduction}

The recognition of ions and molecules is an essential part of supramolecular chemistry. ${ }^{1-5}$ The design and synthesis of chemosensors for heavy and transition metal ions are currently a task of prime importance for medical, environmental and biological applications. $^{6-9}$ Presently one of the most attractive approaches focuses on the research of novel colourimetric metal ion sensors which allows naked eyes a real time and space detection of the change of colour upon metal ion binding without use of any spectroscopic instrument. ${ }^{10-14}$ Chemosensors not only possess simplicity and high sensitivity, but are capable of specific recognition of particular ions in presence of related ones. ${ }^{15-17}$ Iron is the most abundant essen-

*For correspondence tial transition metal and it plays very important roles in various biological processes. ${ }^{18} \mathrm{~A}$ few systems have been designed as selective chemosensors for iron (II)/iron (III) or total iron content. ${ }^{13,19-23}$ In our present work, we report a highly selective colourimetric chromogenic agent for iron(III) with a diacetyl monoxime-2-pyridyl hydrazone ligand, HL, (1), because it would be useful now-a-days to develop simple-to-use, naked eye diagnostic tools.

\section{Experimental}

\subsection{Materials}

All starting materials and solvents were purchased from Aldrich Chemical Company and used without further purification unless otherwise stated. 


\subsection{Physical measurements}

A Perkin Elmer $2400 \mathrm{C}$ elemental analyser was used to collect microanalytical data $(\mathrm{C}, \mathrm{H}, \mathrm{N})$. Sartorius CP64 balance was used for weighing purpose. FTIR data were collected with the help of FTIR 8400 Shimadzu Spectrophotometer. The UV-Vis spectra of the ligand and its complexes were measured on Shimadzu UV-1700 spectrophotometer and corrected for background due to solvent absorption. Emission spectra were carried out with a Perkin Elmer LS 50B Luminescence Spectrometer. For binding constant measurements solutions were prepared at a fixed concentration of HL, $1(1.0 \times$ $\left.10^{-5} \mathrm{M}\right)$ and at a concentration of metal ions ranging from $(1 \cdot 0$ to $10 \cdot 0) \times 10^{-6} \mathrm{M}$ at room temperature. Electrochemical measurements were performed in aqueous medium under nitrogen atmosphere on a Versastat II PAR Electrochemistry system using a platinum electrode. $\mathrm{NH}_{4} \mathrm{PF}_{6}$ was used as a supporting electrolyte and the potentials are referenced to the $\mathrm{Ag} / \mathrm{AgCl}$ electrode. Solution electrical conductivities were measured with the help of a Philips PR 9500 bridge, the solute concentration being $10^{-3} \mathrm{M}$. For spectroscopic measurements HPLC grade solvents were used.

\section{$2.3 X$-ray structure determination of $\left[\mathrm{Ni}^{I I}(\mathrm{HL})_{2}\right] \mathrm{Cl}_{2}, \mathbf{1} \mathbf{b}$}

The plate-like brown coloured crystals of $\left[\mathrm{Ni}^{\mathrm{II}}(\mathrm{HL})_{2}\right] \mathrm{Cl}_{2}, \mathbf{1 b}$, were grown by slow evaporation of methanol at room temperature and mounted on a glass fibre. Intensity data for the complex $\mathbf{1 b}$ was

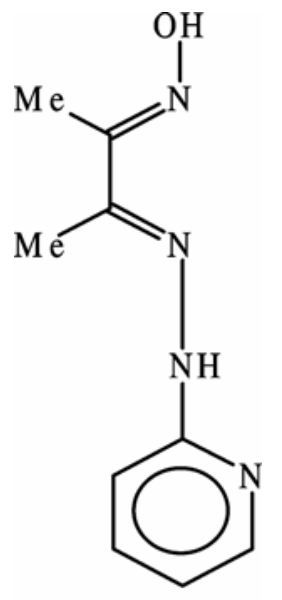

HL, 1 collected at $173 \mathrm{~K}\left(-100^{\circ} \mathrm{C}\right)$ by the $\omega$-scan method over the $2 \theta$ range $1.36-25.71^{\circ}$ on a Stoe Mark IIImage plate diffraction system ${ }^{24}$ equipped with a two-circle goniometer and using $\mathrm{MoK} \alpha$ graphite monochromated radiation $(\lambda=0.71073 \AA)$. Structure solution and refinement were done by direct methods using SHELXS-97 and SHELXL-97 programs. ${ }^{25-27}$ The structure was successfully solved in space group $P 2_{1} /$ c. Of the 10986 independent reflections, 8494 satisfying $I>2 \sigma(I)$ were used for structure solution. All non-hydrogen atoms were refined anisotropically. An absorption correction was applied using MULscanABS in PLATON. ${ }^{28}$ The molecular structure and crystallographic numbering scheme are illustrated in the PLATON drawing. ${ }^{28}$ Details regarding the crystallographic structure determination are given in table 1 . We were unable to crystallize the iron(III) complex 1a, but the elemental analysis and the stoichiometric studies (vide supra) confirm the $1: 2$ binding in $\left[\mathrm{Fe}^{\mathrm{III}}(\mathrm{HL})_{2}\right] \mathrm{Cl}_{3}, \mathbf{1} \mathbf{a}$.

Table 1. Crystallographic data for $\left[\mathrm{Ni}^{\mathrm{II}}(\mathrm{HL})_{2}\right] \mathrm{Cl}_{2}, \mathbf{1 b}$.

\begin{tabular}{|c|c|}
\hline Compound & $\mathbf{1 b}$ \\
\hline Formula & $\mathrm{C}_{18} \mathrm{H}_{38} \mathrm{Cl}_{2} \mathrm{~N}_{8} \mathrm{NiO}_{9}$ \\
\hline Formula mass & $640 \cdot 17$ \\
\hline$T(\mathrm{~K})$ & $173(2) \mathrm{K}$ \\
\hline Wavelength $(\AA)$ & 0.71073 \\
\hline Crystal system & Monoclinic \\
\hline Space group & $P 2_{1} / c$ \\
\hline$a(\AA)$ & $11 \cdot 881(4)$ \\
\hline$b(\AA)$ & $17 \cdot 824(7)$ \\
\hline$c(\AA)$ & $28 \cdot 953(9)$ \\
\hline$\alpha\left(^{\circ}\right)$ & 90 \\
\hline$\beta\left(^{\circ}\right)$ & $108 \cdot 427(2)$ \\
\hline$\gamma\left({ }^{\circ}\right)$ & 90 \\
\hline$V\left[\AA^{3}\right]$ & $5817 \cdot 2$ \\
\hline$Z$ & 8 \\
\hline$D_{\text {calc }}\left(\mathrm{g} / \mathrm{cm}^{-3}\right)$ & $1 \cdot 462$ \\
\hline$\mu\left(\mathrm{mm}^{-1}\right)$ & 0.908 \\
\hline$F(000)$ & 2688 \\
\hline Limiting indices & $\begin{array}{l}-14<h<14,-21<k<21 \\
-35<l<35\end{array}$ \\
\hline Reflns collected/unique & $10986 / 8494$ \\
\hline Refinement method & $\begin{array}{l}\text { Full-matrix least-squares } \\
\text { on }|F|\end{array}$ \\
\hline Data/restraints/parameters & $10986 / 4 / 578$ \\
\hline GOF on $F^{2}$ & $1 \cdot 039$ \\
\hline$R 1^{[\mathrm{a}]}, w R 2^{[\mathrm{b}]}[I>2 \sigma(I)]$ & $R 1=0.0841, \mathrm{w} R 2=0.1974$ \\
\hline$R 1^{[\mathrm{a}]}, w R 2^{[\mathrm{b}]}$ (all data) & $R 1=0.0670, w R 2=0.1876$ \\
\hline $\begin{array}{l}\text { Largest diff. peak } \\
\text { and hole }\left(\mathrm{e} \AA^{-3}\right)\end{array}$ & $1 \cdot 232,-1 \cdot 326$ \\
\hline
\end{tabular}




\subsection{Syntheses of ligand and complexes}

2.4a Diacetyl monoxime-2-pyridyl hydrazone ligand, HL, 1: The ligand was prepared by the same general procedure as before. ${ }^{29,30}$

2.4b Synthesis of $\left[\mathrm{Fe}^{I I I}(\mathrm{HL})_{2}\right] \mathrm{Cl}_{3}, \mathbf{1} \mathbf{a}$ : To a stirred methanolic solution of anhydrous iron(III) chloride $(0.03 \mathrm{~g}, 0.2 \mathrm{mmol})$ was added a solution of HL, 1 , $(0.03 \mathrm{~g}, 0.4 \mathrm{mmol})$ in methanol $(5 \mathrm{ml})$ and the resulting reddish-pink solution was stirred for $0.5 \mathrm{~h}$. The solvent was evaporated by rotary evaporator and recrystallized from methanol. Yield. $0.10 \mathrm{~g}$, 84\%. Anal. calc. for $\mathrm{C}_{18} \mathrm{H}_{24} \mathrm{~N}_{8} \mathrm{O}_{2} \mathrm{Cl}_{3} \mathrm{Fe}$ : C $39.53, \mathrm{H}$ 4.39, N 20.49; found C 39.56, H 4.38, N 20.50\%. Selected FTIR data, $v\left(\mathrm{~cm}^{-1}\right): 3425,3271,2925$, $1649,1616,1554,1481,1448,1319,1282,1259$, $1218,1110,1091,931,817,769,626,524,499$, 464. UV-Vis $\left(\mathrm{CH}_{3} \mathrm{OH}\right), \lambda_{\max }(\mathrm{nm})\left(\varepsilon, \mathrm{M}^{-1} \mathrm{~cm}^{-1}\right)$ : 487(8400), 350 (27000), 287 (32000), 240 (40000).

2.4c Synthesis of $\left[\mathrm{Ni}^{\mathrm{II}}(\mathrm{HL})_{2}\right] \mathrm{Cl}_{2}, \mathbf{1} \mathbf{b}$ : To a stirred methanolic solution of $\mathrm{NiCl}_{2} \cdot 6 \mathrm{H}_{2} \mathrm{O} \quad(0.04 \mathrm{~g}$, $0.2 \mathrm{mmol})$ was added a solution of HL, $1,(0.03 \mathrm{~g}$, $0.4 \mathrm{mmol})$ in methanol $(5 \mathrm{ml})$ and the resulting brown solution was stirred for $0.5 \mathrm{~h}$. The solvent was evaporated by rotary evaporator and on recrystallization from methanol deep brown crystals of the complex was obtained. Yield $0 \cdot 11 \mathrm{~g}, 86 \%$. Anal. calc. for $\mathrm{C}_{18} \mathrm{H}_{38} \mathrm{Cl}_{2} \mathrm{~N}_{8} \mathrm{NiO}_{9}$ : $\mathrm{C} 33.74, \mathrm{H}$ 5.93, N 17.49; found C 33.76 , H 5.94, N 17.48\%. Selected FTIR data, $v\left(\mathrm{~cm}^{-1}\right): 3398,3164,3109,3060,2968$, $2918,1645,1616,1573,1481,1427,1380,1309$, $1280,1251,1222,1135,1060,1010,966,902,806$, 773, 526, 476. UV-Vis $\left(\mathrm{CH}_{3} \mathrm{OH}\right), \lambda_{\max }(\mathrm{nm})(\varepsilon$, $\left.\mathrm{M}^{-1} \mathrm{~cm}^{-1}\right)$ : 448 (8500), 352 (29000), 289 (34000), 240 (40000).

\subsection{Stoichiometry calculation}

The metal to ligand ratio $(n)$ for the complexation reaction was ascertained by Job's method of continuous variation.

2.5a Job's method of continuous variation: This method is performed by preparing several solutions consisting of varying amounts of the metal ion and the ligand, however the sum of the metal ion concentration and the ligand concentration is constant for each solution. The absorbance of each solution is measured and plotted against the mole fraction of metal ion or the mole fraction of ligand. The mole fraction of the metal, $M$, is defined as

$$
\text { Mole fraction }=C_{\mathrm{m}} /\left(\mathrm{C}_{\mathrm{m}}+\mathrm{C}_{1}\right) \text {, }
$$

where $C_{\mathrm{m}}=$ the concentration of the metal and $C_{1}=$ the concentration of the ligand.

\section{Results and discussion}

\subsection{Synthesis and characterization}

The ligand HL, 1 used in the present work is tridentate in nature incorporating pyridyl, imine and oxime $\mathrm{N}$-atoms as potential donor sites. It reacts with anhydrous $\mathrm{FeCl}_{3}$ and $\mathrm{NiCl}_{2} \cdot 6 \mathrm{H}_{2} \mathrm{O}$ in methanol at room temperature in $1: 2$ molar ratio to afford reddish-pink and brown coloured complexes $\left[\mathrm{Fe}^{\mathrm{III}}(\mathrm{HL})_{2}\right] \mathrm{Cl}_{2}, \mathbf{1} \mathbf{a}$ and $\left[\mathrm{Ni}^{\mathrm{II}}(\mathrm{HL})_{2}\right] \mathrm{Cl}_{2}, \mathbf{1 b}$ in high yields. The elemental analysis data are consistent with their empirical formulae. All the complexes are soluble in methanol and sparingly soluble in water. Room temperature $(298 \mathrm{~K})$ magnetic moments of complexes 1a and 1b are $4.9 \mu_{\beta}(S=2)$ and $2.84 \mu_{\beta}$ $(S=1)$ respectively, corresponding to the high spin configuration in both the cases.

\subsection{Spectral studies}

All the spectroscopic measurements were carried out in degassed methanol at room temperature. The bands appearing in the UV region (200-340 nm) are characteristics of the ligand, HL, 1. In the complexes these ligand centered bands are accompanied by multiple bands extending into the visible region $(350-500 \mathrm{~nm})$. On excitation at $285 \mathrm{~nm}$, the ligand $\mathrm{HL}, 1$ strongly emits at $364 \mathrm{~nm}$ due to an intraligand ${ }^{1}\left(\pi-\pi^{*}\right)$ transition. The complexes are luminescent $\left(\lambda_{\mathrm{ex}}=285 \mathrm{~nm}, \lambda_{\mathrm{em}}=365 \mathrm{~nm}\right)$ with $F / F_{0} 0.75$ for $1 \mathbf{a}$ and 0.81 for $1 \mathbf{b}$. The absorption maxima of the ligand are decreased linearly with increase of metal ion concentration $\left(1 \times 10^{-6} \mathrm{M}\right)$. With $\mathrm{M}^{2+} /$ ligand $\mathrm{HL}$ mole ratio $1: 2$, a characteristic peak is developed at $487 \mathrm{~nm}$ for the iron(III) complex 1a with clear isosbestic point at $327 \mathrm{~nm}$ (figure 1). The absorption peak generated in the visible region is maximum red shifted in case of complex 1a, with a distinct colour change from yellow to reddish-pink which can easily be read through naked eyes without any spectroscopic instrument (figure 2). In order to study the effects of other metal ions, competition experiments were conducted in presence of $\mathrm{Fe}^{3+}$ that is also 
mixed with $\mathrm{Na}^{+}, \mathrm{K}^{+}, \mathrm{Ca}^{2+}, \mathrm{Mg}^{2+}, \mathrm{Al}^{3+}, \mathrm{Mn}^{2+}, \mathrm{Ni}^{2+}$, $\mathrm{Cu}^{2+}, \mathrm{Zn}^{2+}, \mathrm{Co}^{2+}, \mathrm{Pb}^{2+}, \mathrm{Hg}^{2+}, \mathrm{Cd}^{2+}$ ions at $10^{-5} \mathrm{M}$. No obvious interference was observed in presence of other metal ions as shown in table 2. Thus the ligand HL, 1 can be effectively used as a chromogenic agent for $\mathrm{Fe}^{3+}$.

\subsection{Thermodynamics of binding}

The association constant $\left(K_{\text {ass }}\right)$ of complexes can be estimated spectrophotometrically (figure 1) according to the (1), ${ }^{29,31}$ where $X$ represents the absorption intensity, $X_{\lim }$ represents the absorption intensity at full complexation, $C_{0}$ is the initial concentration of the ligand, $C_{\mathrm{H}}$ and $C_{\mathrm{G}}$ are the corresponding concentrations of the ligand and metal ion during titration. The $K_{\text {ass }}$ (UV-Vis) was found to be $(6.4865 \pm$ $0.004) \times 10^{5}$ for $1 \mathrm{a}$ which was higher than $1 \mathbf{b}\left(K_{\text {ass }}\right.$ (UV-Vis) $1.1960 \pm 0.002) \times 10^{5}$ ) at $298 \mathrm{~K}$.

$$
\begin{aligned}
X= & X_{\mathrm{o}}+\left(X_{\lim }-X_{\mathrm{o}}\right) / 2 C_{0}\left\{C_{\mathrm{H}}+C_{\mathrm{G}}+1 / K_{\mathrm{ass}}\right. \\
& \left.-\left[\left(C_{\mathrm{H}}+C_{\mathrm{G}}+1 / K_{\text {ass }}\right)^{2}-4 C_{\mathrm{H}} C_{\mathrm{G}}\right]^{1 / 2}\right\} .
\end{aligned}
$$

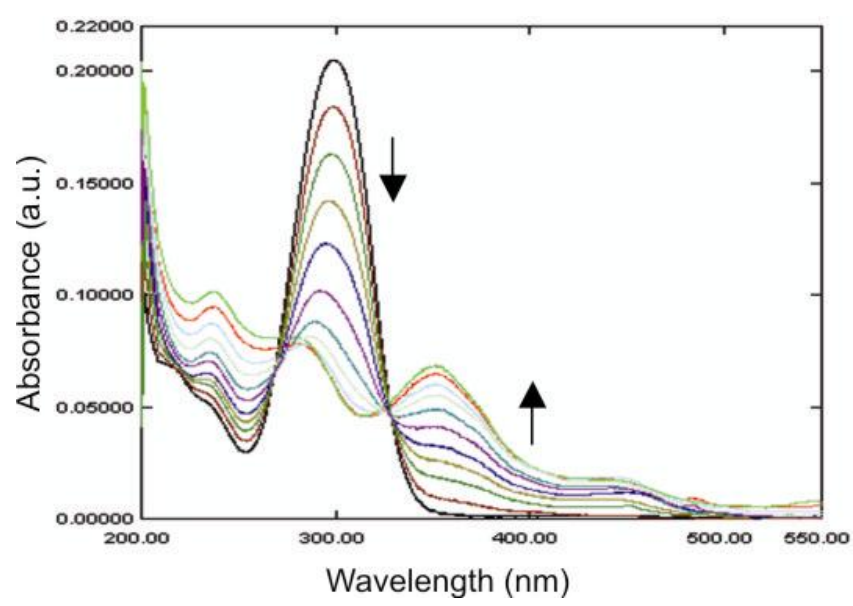

Figure 1. Absorbance spectra of HL, 1, $\left(1.0 \times 10^{-5} \mathrm{M}\right)$ upon addition of $\mathrm{Fe}(\mathrm{III}) .\left(1.0 \times 10^{-6} \mathrm{M}-1.0 \times 10^{-5} \mathrm{M}\right)$ in degassed methanol $(\mathrm{pH}=7.0)$ at $298 \mathrm{~K}$.

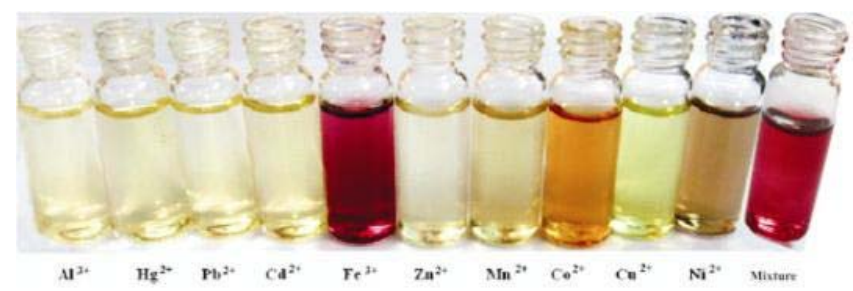

Figure 2. The photograph of ligand HL, 1 in methanol solution after the addition of different metal ions and the mixture $\left(\mathrm{Fe}^{3+}, \mathrm{Co}^{2+}, \mathrm{Ni}^{2+}\right.$ and $\left.\mathrm{Cu}^{2+}\right)$.
The temperature dependence of binding constant was studied between $293-308 \mathrm{~K}$ and the values of the thermodynamic parameters for the binding were obtained by variable temperature UV-Vis titration in degassed methanol at $298 \mathrm{~K}$. The standard Gibb's energy change, $\Delta G^{0}$, the standard enthalpy change, $\Delta H^{0}$ and the standard entropy change, $\Delta S^{0}$ which are listed in table 3, are calculated using Vant Hoff's equation. The stoichiometry $(n)$ of the complexes $\mathbf{1 a}$ and $\mathbf{1 b}$ is confirmed by the Job's plot (table 3).

\subsection{Metal redox}

The redox properties of $\mathbf{1 a}$ and $\mathbf{1 b}$ have been studied in double distilled deionized water by cyclic voltammetry using a platinum working electrode. The complex 1a exhibits quasi reversible single reductive response $\left(E_{\mathrm{Fe}(\mathrm{III} / \mathrm{II})}, 0 \cdot 10 \mathrm{~V} ; \Delta E \mathrm{p}=280 \mathrm{mV}\right.$ vs $\mathrm{Ag} / \mathrm{AgCl}$ ) and the complex $1 \mathrm{~b}$ shows single oxidative response $\left(E_{\mathrm{Ni}(\mathrm{II} / \mathrm{III}),}, 0.70 \mathrm{~V} ; \Delta E_{\mathrm{p}}=240 \mathrm{mV}\right.$ vs $\mathrm{Ag} / \mathrm{AgCl})$ under nitrogen atmosphere. A representative diagram of the cyclic voltammogram of the complex 1a is shown in figure 3 .

Attempted isolation of the bivalent species for 1a did not succeed due to its rapid oxidation in air.

\subsection{Molecular Srtucture of $\left[\mathrm{Ni}^{\mathrm{II}}(\mathrm{HL})_{2}\right] \mathrm{Cl}_{2}, \mathbf{1 b}$}

The molecular structure of $\left[\mathrm{Ni}^{\mathrm{II}}(\mathrm{HL})_{2}\right] \mathrm{Cl}_{2}, \mathbf{1} \mathbf{b}$ clearly shows that ligand binds to the metal in a tridentate manner utilizing pyridyl, imine and oxime $\mathrm{N}$-atoms as potential donor sites. Selected bond distances and angles are listed in table 4 . In complex $\mathbf{1} \mathbf{b}$, two crys-

Table 2. Interference of metal ions in the $\mathrm{Fe}^{3+}$ detection.

\begin{tabular}{lc}
\hline $\mathrm{Fe}^{3+}+$ metal ions & Absorbance (at $487 \mathrm{~nm})$ \\
$\mathrm{Fe}^{3+}+\mathrm{Ca}^{2+}$ & $0 \cdot 124$ \\
$\mathrm{Fe}^{3+}+\mathrm{Mg}^{2+}$ & $0 \cdot 122$ \\
$\mathrm{Fe}^{3+}+\mathrm{Al}^{3+}$ & $0 \cdot 122$ \\
$\mathrm{Fe}^{3+}+\mathrm{Hg}^{2+}$ & $0 \cdot 123$ \\
$\mathrm{Fe}^{3+}+\mathrm{Zn}^{2+}$ & $0 \cdot 120$ \\
$\mathrm{Fe}^{3+}+\mathrm{Cu}^{2+}$ & $0 \cdot 116$ \\
$\mathrm{Fe}^{3+}+\mathrm{Cd}^{2+}$ & $0 \cdot 123$ \\
$\mathrm{Fe}^{3+}+\mathrm{Pb}^{2+}$ & $0 \cdot 122$ \\
$\mathrm{Fe}^{3+}+\mathrm{Mn}^{2+}$ & $0 \cdot 122$ \\
$\mathrm{Fe}^{3+}+\mathrm{Co}^{2+}$ & $0 \cdot 119$ \\
$\mathrm{Fe}^{3+}+\mathrm{Ni}^{2+}$ & $0 \cdot 117$ \\
$\mathrm{Fe}^{3+}$ & $0 \cdot 124$ \\
\hline
\end{tabular}

$\mathrm{FeCl}_{3}\left(1.0 \times 10^{-5} \mathrm{M}\right)$ was added to the solution of ligand HL, $1\left(1.0 \times 10^{-5} \mathrm{M}\right)$ in the presence of other metal ions $\left(1.0 \times 10^{-5} \mathrm{M}\right)$ 
Table 3. Binding and thermodynamic parameters for $\mathbf{1 a}$ and $\mathbf{1 b}$.

\begin{tabular}{lccccc}
\hline Complexes & $K_{\text {ass }}$ & $\Delta G^{0}(\mathrm{cal} / \mathrm{M})$ & $\Delta H^{0}(\mathrm{cal} / \mathrm{M})$ & $\Delta S^{0}(\mathrm{cal} / \mathrm{M} / \mathrm{deg})$ & $n$ \\
\hline$\left[\mathrm{Fe}^{\mathrm{III}}(\mathrm{HL})_{2}\right]^{3+}, \mathbf{1 a}$ & $(6.4865 \pm 0 \cdot 004) \times 10^{5}$ & $(-7976.05 \pm 1 \cdot 37)$ & $(-245 \cdot 9 \pm 2 \cdot 01)$ & $(25 \cdot 94 \pm 0 \cdot 054)$ & 0.56 \\
{$\left[\mathrm{Ni}^{\mathrm{II}}(\mathrm{HL})_{2}\right]^{2+}, \mathbf{1 b}$} & $(1.1960 \pm 0 \cdot 002) \times 10^{5}$ & $(-6968 \cdot 37 \pm 4 \cdot 06)$ & $(-399 \cdot 33 \pm 2 \cdot 21)$ & $(22 \cdot 04 \pm 0 \cdot 032)$ & $0 \cdot 53$ \\
\hline
\end{tabular}

Table 4. Selected bond distances $(\AA)$ and angles $\left({ }^{\circ}\right)$ for $\left[\mathrm{Ni}^{\mathrm{II}}(\mathrm{HL})_{2}\right] \mathrm{Cl}_{2}, \mathbf{1 b}$.

\begin{tabular}{llll}
\hline Bond lengths & & & \\
$\mathrm{Ni}(1)-\mathrm{N}(1)$ & $2 \cdot 047(4)$ & $\mathrm{Ni}(1)-\mathrm{N}(3)$ & $2 \cdot 023(4)$ \\
$\mathrm{Ni}(1)-\mathrm{N}(4)$ & $2 \cdot 170(4)$ & $\mathrm{Ni}(1)-\mathrm{N}(5)$ & $2 \cdot 078(3)$ \\
$\mathrm{Ni}(1)-\mathrm{N}(7)$ & $2 \cdot 003(4)$ & $\mathrm{Ni}(1)-\mathrm{N}(8)$ & $2 \cdot 136(3)$ \\
$\mathrm{Ni}(2)-\mathrm{N}(11)$ & $2 \cdot 003(4)$ & $\mathrm{Ni}(2)-\mathrm{N}(12)$ & $2 \cdot 120(3)$ \\
$\mathrm{Ni}(2)-\mathrm{N}(13)$ & $2 \cdot 085(3)$ & $\mathrm{Ni}(2)-\mathrm{N}(9)$ & $1 \cdot 998(4)$ \\
$\mathrm{Ni}(2)-\mathrm{N}(16)$ & $2 \cdot 149(4)$ & & $2 \cdot 076(3)$ \\
Bond angles & & $\mathrm{N}(1)-\mathrm{Ni}(1)-\mathrm{N}(5)$ & \\
$\mathrm{N}(1)-\mathrm{Ni}(1)-\mathrm{N}(4)$ & $154 \cdot 08(15)$ & $\mathrm{N}(1)-\mathrm{Ni}(1)-\mathrm{N}(8)$ & $92 \cdot 74(14)$ \\
$\mathrm{N}(1)-\mathrm{Ni}(1)-\mathrm{N}(7)$ & $103 \cdot 39(14)$ & $\mathrm{N}(3)-\mathrm{Ni}(1)-\mathrm{N}(4)$ & $91 \cdot 97(14)$ \\
$\mathrm{N}(3)-\mathrm{Ni}(1)-\mathrm{N}(1)$ & $78 \cdot 8(2)$ & $\mathrm{N}(3)-\mathrm{Ni}(1)-\mathrm{N}(7)$ & $75 \cdot 25(14)$ \\
$\mathrm{N}(3)-\mathrm{Ni}(1)-\mathrm{N}(5)$ & $99 \cdot 40(15)$ & $\mathrm{N}(4)-\mathrm{Ni}(1)-\mathrm{N}(5)$ & $176 \cdot 85(14)$ \\
$\mathrm{N}(3)-\mathrm{Ni}(1)-\mathrm{N}(8)$ & $106 \cdot 35(15)$ & $\mathrm{N}(4)-\mathrm{Ni}(1)-\mathrm{N}(8)$ & $90 \cdot 30(13)$ \\
$\mathrm{N}(4)-\mathrm{Ni}(1)-\mathrm{N}(7)$ & $102.43(14)$ & $\mathrm{N}(5)-\mathrm{Ni}(1)-\mathrm{N}(8)$ & $96 \cdot 38(13)$ \\
$\mathrm{N}(5)-\mathrm{Ni}(1)-\mathrm{N}(7)$ & $78 \cdot 38(14)$ & $\mathrm{N}(9)-\mathrm{Ni}(2)-\mathrm{N}(15)$ & $154 \cdot 25(14)$ \\
$\mathrm{N}(7)-\mathrm{Ni}(1)-\mathrm{N}(8)$ & $75 \cdot 90(14)$ & $\mathrm{N}(11)-\mathrm{Ni}(2)-\mathrm{N}(12)-\mathrm{N}(15)$ & $79 \cdot 24(15)$ \\
$\mathrm{N}(9)-\mathrm{Ni}(2)-\mathrm{N}(13)$ & $91 \cdot 18(14)$ & $\mathrm{N}(12)-\mathrm{Ni}(2)-\mathrm{N}(13)$ & $176 \cdot 2(2)$ \\
$\mathrm{N}(9)-\mathrm{Ni}(2)-\mathrm{N}(16)$ & $93 \cdot 69(14)$ & $\mathrm{N}(12)-\mathrm{Ni}(2)-\mathrm{N}(16)$ & $95 \cdot 56(14)$ \\
$\mathrm{N}(11)-\mathrm{Ni}(2)-\mathrm{N}(13)$ & $99 \cdot 01(15)$ & $\mathrm{N}(13)-\mathrm{Ni}(2)-\mathrm{N}(16)$ & $91 \cdot 27(14)$ \\
$\mathrm{N}(11)-\mathrm{Ni}(2)-\mathrm{N}(16)$ & $107 \cdot 32(14)$ & $\mathrm{N}(9)-\mathrm{Ni}(2)-\mathrm{N}(11)$ & $153 \cdot 66(14)$ \\
$\mathrm{N}(12)-\mathrm{Ni}(2)-\mathrm{N}(15)$ & $106 \cdot 63(14)$ & $\mathrm{N}(9)-\mathrm{Ni}(2)-\mathrm{N}(12)$ & $78 \cdot 06(14)$ \\
$\mathrm{N}(13)-\mathrm{Ni}(2)-\mathrm{N}(15)$ & $78 \cdot 21(15)$ & & $154 \cdot 08(15)$ \\
$\mathrm{N}(15)-\mathrm{Ni}(2)-\mathrm{N}(16)$ & $75 \cdot 46(14)$ & & \\
\hline
\end{tabular}

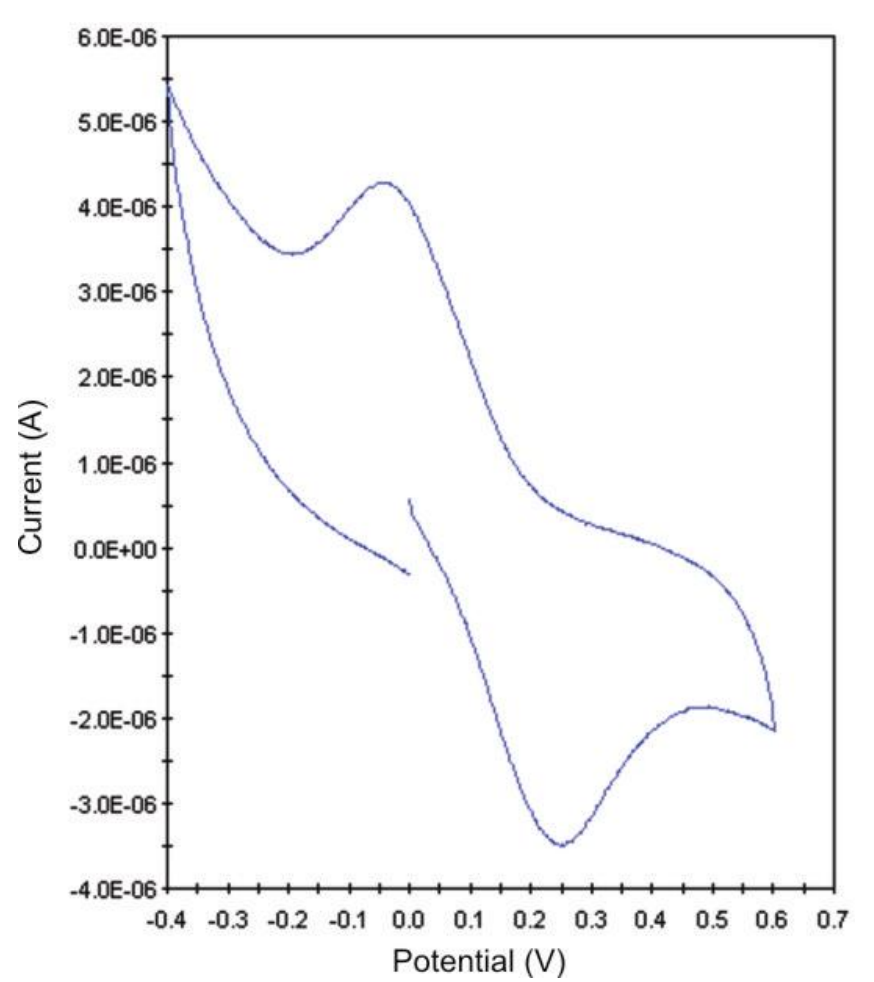

Figure 3. Cyclic voltammogram of $\left[\mathrm{Fe}^{\mathrm{III}}(\mathrm{HL})_{2}\right] \mathrm{Cl}_{3}, \mathbf{1 a}$ in aqueous solution $(\mathrm{pH}=7 \cdot 2)$ at room temperature. tallographically distinct but metrically very similar molecules making an enantiomeric pair constitute the asymmetric unit in which both metal atoms are bis chelated in meridional geometry as shown in figure 4 .

Selected bond lengths of the complex, $1 \mathbf{b}$ has been reported as $\mathrm{Ni}(1)-\mathrm{N}(1) 2.047(4) \AA$, $\mathrm{Ni}(1)-\mathrm{N}(3)$ 2.023(4) $\AA, \quad \mathrm{Ni}(1)-\mathrm{N}(4) \quad 2 \cdot 170(4) \AA, \quad \mathrm{Ni}(1)-\mathrm{N}(5)$ $2.078(3) \AA, \quad \mathrm{Ni}(1)-\mathrm{N}(7) \quad 2.003(4) \AA, \quad \mathrm{Ni}(1)-\mathrm{N}(8)$ $2 \cdot 136(3) \AA . \quad \mathrm{Ni}(2)-\mathrm{N}(11) 2.003(4) \AA, \mathrm{Ni}(2)-\mathrm{N}(12)$ $2 \cdot 120(3) \AA, \quad \mathrm{Ni}(2)-\mathrm{N}(13) \quad 2 \cdot 085(3) \AA, \mathrm{Ni}(2)-\mathrm{N}(15)$ 1.998(4) $\AA, \quad \mathrm{Ni}(2)-\mathrm{N}(16) \quad 2 \cdot 149(4) \AA, \quad \mathrm{Ni}(2)-\mathrm{N}(9)$ 2.076(3) $\AA$. The four five-membered rings are almost planar. The $\mathrm{NiN}_{6}$ coordination spheres are distorted from octahedral geometry as can be seen from the angles at the metal centres. The angles at the metal centre between the cis-positioned donor pairs span the range $75 \cdot 25(14)^{\circ}-106 \cdot 35(15)^{\circ}$ and those between the trans-positioned pairs are $154.08(15)-176.85(14)^{\circ}$ for the centre $\mathrm{Ni}(1)$, whereas for the centre $\mathrm{Ni}(2)$ the angles at the metal centre between the cis-positioned donor pairs span the range $75 \cdot 46(14)^{\circ}-107 \cdot 32(14)^{\circ}$ and those 
between the trans-positioned pairs are $153 \cdot 66(14)^{\circ}-$ $176 \cdot 2(2)^{\circ}$. The average $\mathrm{Ni}-\mathrm{N}_{\mathrm{Ox}}$ distance is $\sim 2 \cdot 14 \AA$ which is much longer than the reported $\mathrm{Ni}-\mathrm{N}_{\mathrm{Ox}}$ distance $22.04 \AA{ }^{32}$ where oxime is deprotonated.

\section{Conclusion}

In conclusion, we have designed a highly selective chromogenic agent for detection of iron(III) via design of a heterocyclic hydrazone ligand, diacetyl monoxime-2-pyridyl hydrazone HL, 1 . The ligand shows a remarkable colour change with iron(III) from yellow to reddish-pink that exhibits a characteristic absorption peak at $487 \mathrm{~nm}$. The change in colour can easily be distinguished from other metal complexes by the naked eye. No obvious interference was observed in presence of other metal ions $\left(\mathrm{Ca}^{2+}, \mathrm{Mg}^{2+}, \mathrm{Al}^{3+}, \mathrm{Pb}^{2+}, \mathrm{Hg}^{2+}, \mathrm{Cd}^{2+}, \mathrm{Mn}^{2+}, \mathrm{Na}^{+}, \mathrm{K}^{+}\right.$, $\mathrm{Co}^{2+}, \mathrm{Ni}^{2+}, \mathrm{Cu}^{2+}$ and $\left.\mathrm{Zn}^{2+}\right)$. The association constant $\left(K_{\text {ass }}, \mathrm{UV}-\mathrm{Vis}\right)$ was found to be $(6.4865 \pm 0.004) \times$ $10^{5}$ for the complex 1a and $(1 \cdot 1960 \pm 0.002) \times 10^{5}$ for the complex $\mathbf{1 b}$ at $298 \mathrm{~K}$ determined by the UVVis spectroscopy. On excitation at $285 \mathrm{~nm}$, the ligand 1 strongly emits at $364 \mathrm{~nm}$ due to an intraligand ${ }^{1}\left(\pi-\pi^{*}\right)$ transition. Both the complexes are also luminescent ( $\lambda_{\mathrm{ex}}=285 \mathrm{~nm}, \lambda_{\mathrm{em}}=365 \mathrm{~nm}, F / F_{0}$ 0.75 for $1 \mathbf{a}$ and 0.81 for $1 \mathbf{b})$. The $1: 2$ binding of the $\mathrm{Fe}^{3+}$ and $\mathrm{Ni}^{2+}$ with the ligand in the complexes $1 \mathrm{a}$ and $\mathbf{1 b}$ is confirmed by Job's method. In complex 1b, two crystallographically distinct but metrically very similar molecules making an enantiomeric pair constitute the asymmetric unit in which both metal atoms are tris chelated in meridional $\mathrm{NiN}_{6}$ geometry.
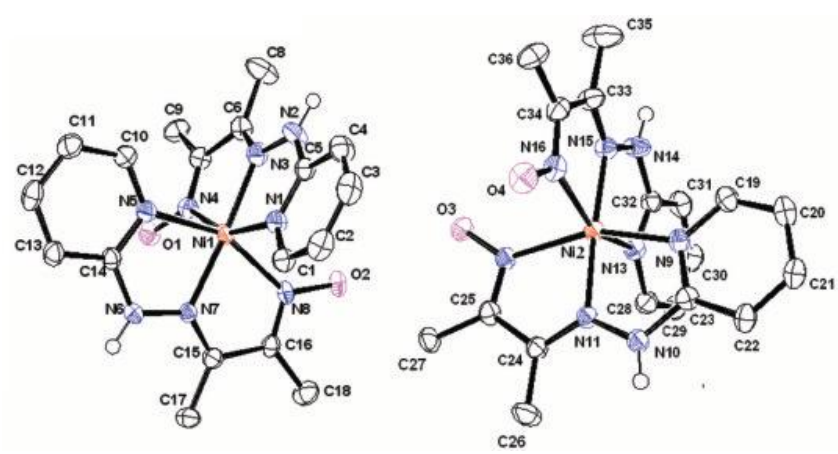

Figure 4. Molecular strucure of the complex, $\left[\mathrm{Ni}^{\mathrm{II}}(\mathrm{HL})_{2}\right] \mathrm{Cl}_{2}$, 1b with thermal ellipsoids drawn at the $50 \%$ probability level. The water molecules have been omitted for clarity.

\section{Supplementary material}

Crystallographic data for the complex $\left[\mathrm{Ni}^{\mathrm{iI}}(\mathrm{HL})_{2}\right]$ $\mathrm{Cl}_{2}, \mathbf{1 b}$ in the CIF format has been deposited with the Cambridge Crystallographic Data Center, CCDC No. 715865. These data can be obtained free of charge via http://www.ccdc.cam.ac.uk/conts/retrieving.html, or from the Cambridge Crystallographic Data Centre, 12 Union Road, Cambridge CB2 1EZ, UK; fax: (+44) 1223-336-033; e-mail: deposit@ ccdc.cam.ac.uk.

\section{Acknowledgements}

Financial support received from University Grants Commission (UGC), New Delhi; Council of Scientific and Industrial Research (CSIR), New Delhi and Department of Science and Technology (DST)FIST, New Delhi are gratefully acknowledged. We are also grateful to the University of Kalyani for providing facilities.

\section{References}

1. De silva A P, McCaughan B, McKinney B O F and Querol M 2003 Dalton Trans. 1902

2. Lavigne J J and Anslyn E V 2001 Angew. Chem. Int. ed. 403119

3. Fabrizzi L, Licchelli M and Pallavicini P 1999 Acc. Chem. Res. 32846

4. Czarnik A W 1994 Acc. Chem. Res. 27302

5. Fabrizzi L and Poggi A 1995 Chem. Soc. Rev. 197

6. De Silva A P, Gunaratne H Q N, Gunnlaugsson T, Huxley A J M, McCoy C P, Rademacher J T and Rice T E 1997 Chem. Rev. 971515

7. Valeur B and Leray I 2000 Coord. Chem. Rev. 205 3

8. De Silva A P, Fox D B, Huxley A J M and Moody T S 2000 Coord. Chem. Rev. 20559

9. Boening D W 2000 Chemosphere 401335

10. Mu H, Gong R, Ma Q, Sun Y and Fu E 2007 Tetrahedron Lett. 485525 and references therein

11. Saravanakumar D, Devaraj S, Iyyampillai S, Mohandoss K and Kandaswamy M 2008 Tetrahedron Lett. 49127

12. Gunnlaugsson T, Leonard J P and Murray N S 2004 Org. Lett. 61557

13. Liang Z-Q, Wang C-X, Yang J-X, Gao H-W, Tian Y-P, Tao X-T and M-H Jiang 2007 New J. Chem. 31 906 and references therein

14. Gil C D, Caballero A, Ratera I, Tárraga A, Molina P and Veciana J 2007 Sensors 73481

15. Desvergne J P and Czarnik A W 1997 Chemosensors for ions and molecular recognition (The Netherlands: Kluwer Academic, Dordrecht) 
16. Zeng Q, Cai P, Li Z, Qin J and Tang B Z 2008 Chem. Commun. 1094

17. Ghosh T, Maiya B G and Samanta A 2006 Dalton Trans. 795 and references therein

18. Fausto da Silva J J R and Williams R J P 1992 The biological chemistry of the elements (New York: Oxford University)

19. Kimura M, Horai T, Hanabusa K and Shirai H 1998 Adv. Mater 10459

20. Yao J, Dou W, Qin W and Liu W 2009 Inorg. Chem. Commun. 12116

21. Zhang H-M, Fu W-F, Chi S-M and Wang J 2009 J. Luminescence 129589

22. Zhang L, Fan J and Peng X 2009 Spectrochim. Acta Part A73 398

23. Singh N, Kaur N, Dunn J, MacKay M and Callan J F 2009 Tetrahedron Lett. 50953
24. Stoe. X-Area V1.26 and X-RED32 V1.26 Software. Stoe \& Cie GmbH 2005 Darmstadt, Germany

25. Sheldrick G. M. A short history of SHELX 2008 Acta Crystallogr. A64 112

26. Sheldrick G M 1990 'SHELXS-97 program for crystal structure determination' Acta Crystallogr. A46 467

27. Sheldrick G M 1999 'SHELXL-97', Universität Göttingen, Göttingen, Germany

28. Spek A L 2003 J. Appl. Cryst. 367

29. Basu C, Biswas S, Chattopadhyay A P, Evans H S and Mukherjee S 2008 Eur. J. Inorg. Chem. 4927

30. Kabil M A, Akl M A and Khalifa M E 1999 Anal. Sci. 15433

31. Liu Y, Li B, You C-C, Wada T and Inoue Y 2001 J. Org. Chem. 66225

32. Pramanik K, Karmakar S, Chowdhury S B and Chakravorty A 1997 Inorg. Chem. 363562 